\title{
Prediabetes and its impact on clinical outcome after coronary intervention in a broad patient population
}

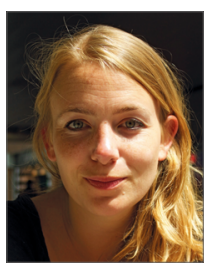

Marlies M. Kok ${ }^{1}$, MD; Clemens von Birgelen ${ }^{1,2 *}, \mathrm{MD}, \mathrm{PhD}$;

Naveed Sattar ${ }^{3}, \mathrm{MD}, \mathrm{PhD}$; Paolo Zocca ${ }^{1}, \mathrm{MD}$; Marije M. Löwik ${ }^{1}, \mathrm{PhD}$;

Peter W. Danse ${ }^{4}, \mathrm{MD}, \mathrm{PhD}$; Carl E. Schotborgh ${ }^{5}, \mathrm{MD}$; Martijn Scholte ${ }^{6}, \mathrm{MD}$;

Marc Hartmann ${ }^{1}, \mathrm{MD}, \mathrm{PhD}$; Gert D. Kant ${ }^{7}, \mathrm{MD}$; Cees Doelman ${ }^{8}, \mathrm{PhD}$;

Melvyn Tjon Joe Gin ${ }^{4}$, MD; Martin G. Stoel ${ }^{1}, \mathrm{MD}, \mathrm{PhD}$; Gert van Houwelingen ${ }^{1}, \mathrm{MD}$;

Gerard C.M. Linssen9 ${ }^{9}$ MD, PhD; Maarten J. IJzerman², PhD; Carine J.M. Doggen², PhD;

Liefke C. van der Heijden ${ }^{1}, \mathrm{MD}, \mathrm{PhD}$

1. Thoraxcentrum Twente, Medisch Spectrum Twente, Enschede, the Netherlands; 2. Health Technology and Services Research, MIRA-Institute of Technical Medicine and Biomedical Technology, University of Twente, Enschede, the Netherlands; 3. Institute of Cardiovascular and Medical Sciences, University of Glasgow, Glasgow, United Kingdom; 4. Rijnstate Hospital, Arnhem, the Netherlands; 5. Haga Hospital, The Hague, the Netherlands; 6. Albert Schweitzer Hospital, Dordrecht, the Netherlands; 7. Internal Medicine, Medisch Spectrum Twente, Enschede, the Netherlands; 8. Clinical Laboratory, Medlon b.v., Medisch Spectrum Twente, Enschede, the Netherlands; 9. Hospital Group Twente, Almelo/Hengelo, the Netherlands

This paper also includes supplementary data published online at: http://www.pcronline.com/eurointervention/142nd_issue/188

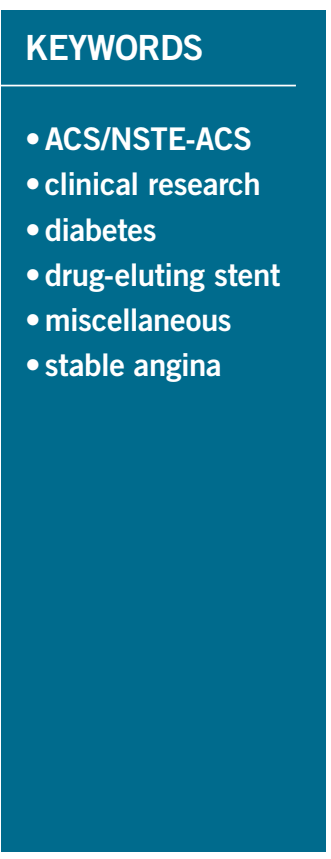

\section{Abstract}

Aims: It is unclear whether detection of prediabetes (pre-DM) by routine assessment of glycated haemoglobin Alc (HbAlc) and fasting plasma glucose (FPG) among patients undergoing percutaneous coronary intervention (PCI) with contemporary drug-eluting stents (DES) may help identify subjects with increased event risk. We assessed the relation between glycaemia status and one-year outcome after PCI.

Methods and results: Glycaemia status was determined in 2,362 non-diabetic BIO-RESORT participants, treated at all four study sites, to identify pre-DM (HbAlc $42-47 \mathrm{mmol} / \mathrm{mol}$; FPG 6.1-6.9 mmol/L) and unknown diabetes mellitus (DM) ( $\mathrm{HbAlc} \geq 48 \mathrm{mmol} / \mathrm{mol}$; FPG $\geq 7.0 \mathrm{mmol} / \mathrm{L}$ ). Another 624 patients had medically treated DM. The main composite endpoint consisted of death, myocardial infarction, or revascularisation. Glycaemic state was known in 2,986 participants: 324 (11\%) patients had pre-DM, 793 (27\%) had DM (known or new), and 1,869 (63\%) patients had normoglycaemia. Pre-DM and DM patients differed from normoglycaemic patients in cardiovascular risk factors. The composite endpoint occurred in $11.1 \%$ in pre-DM, $10.5 \%$ in DM, and $5.7 \%$ in normoglycaemia $(\mathrm{p}<0.001)$. Pre-DM was associated with a twofold higher event risk compared to normoglycaemia (adj. HR 2.0, 95\% CI: 1.4-3.0).

Conclusions: Following PCI with contemporary DES, all-comers with pre-DM had significantly higher event risks than normoglycaemic patients. In non-DM patients requiring PCI, routine assessment of $\mathrm{HbAlc}$ and FPG appears to be of value to identify subjects with increased event risk.

*Corresponding author: Thoraxcentrum Twente, Medisch Spectrum Twente, Koningsplein 1, 7512 KZ Enschede, the Netherlands. E-mail: c.vonbirgelen@mst.nl 


$\begin{array}{ll}\text { Abbreviations } \\ \text { DES } & \text { drug-eluting stents } \\ \text { DM } & \text { diabetes mellitus } \\ \text { FPG } & \text { fasting plasma glucose } \\ \text { HbA1c } & \text { haemoglobin A1c } \\ \text { IEC } & \text { international expert committee } \\ \text { MACE } & \text { major adverse cardiac events } \\ \text { NG } & \text { normoglycaemia } \\ \text { NICE } & \text { National Institute for Health and Care Excellence } \\ \text { pre-DM } & \text { prediabetes }\end{array}$

\section{Introduction}

Before the onset of type 2 diabetes mellitus (DM), some patients can, for many years, experience an abnormal glucose metabolism which is a risk factor for coronary artery disease ${ }^{1,2}$. A metabolic state with borderline high glucose levels that do not meet the diabetes mellitus (DM) criteria is referred to as prediabetes (pre-DM), although some prefer the term risk of diabetes ${ }^{3}$. Pre-DM can be detected by measuring glycated haemoglobin A1c (HbA1c), which gives an indication of long-term blood glucose concentration, and fasting plasma glucose (FPG) ${ }^{4,5}$. Because $\mathrm{HbAlc}$ measurements do not require fasting or a glucose load and are not affected by acute changes in glucose levels due to stress or acute illness, they are easy to use in emergency settings and show only limited withinday or day-to-day variation ${ }^{4-7}$.

General population studies have investigated the association between cardiovascular risk and glucose abnormalities to a great extent, showing in subjects without known DM that elevated $\mathrm{HbA} 1 \mathrm{c}$ is a risk factor for cardiovascular events ${ }^{2,8}$. In addition, in patients with or without known DM, who had an ST-elevation MI, elevated HbA1c levels were associated with increased mortality $^{4,9,10}$. Moreover, DM increases the event risk after coronary stenting ${ }^{11-15}$. Nevertheless, there is a lack of data on the potential relevance of pre-DM for clinical outcome of all-comer patients with proven obstructive coronary disease, who require percutaneous treatment with current drug-eluting stents (DES).

The BIO-RESORT randomised trial recently examined the outcome of all-comer patients who underwent percutaneous coronary intervention (PCI) with implantation of contemporary DES, showing similar and very low clinical event rates for all stents used ${ }^{16}$. In this pre-specified analysis of the BIO-RESORT trial, we assessed the relation between pre-DM and one-year clinical outcome after PCI.

Editorial, see page 968

\section{Methods}

\section{STUDY DESIGN AND PATIENTS}

In the investigator-initiated, multicentre, randomised BIORESORT trial, all-comer patients were treated with PCI and contemporary biodegradable polymer or durable polymer DES. Both the design and the primary outcome of BIO-RESORT, which is registered at ClinicalTrials.gov (NCT01674803), have been described previously ${ }^{16}$. All four clinical study sites, located in the Netherlands, were encouraged to determine HbAlc levels at baseline in non-DM patients in order to identify patients with pre$\mathrm{DM}$ or newly diagnosed DM; if no HbAlc levels were available, the FPG levels were used. In addition, the presence of known DM was recorded in the study files. HbA1c was measured using Tina-quant ${ }^{\circledR} 3^{\text {rd }}$ generation assay on a Cobas 6000 analyser (Roche Diagnostics, Almere, the Netherlands) or CAPILLARYS 2 (Sebia, Lisses, France) calibrated using IFCC standards. The trial complied with the CONSORT 2010 Statement and the Declaration of Helsinki and was approved by the Medical Ethics Committee Twente and the institutional review boards of all participating centres. All patients provided written informed consent.

\section{GLYCAEMIC CATEGORIES}

Based on HbA1c and FPG levels measured at the index hospitalisation, and medical history, patients were stratified into three groups. Glycaemic categories were based on the National Institute for Health and Care Excellence (NICE) ${ }^{17}$ and International Expert Committee (IEC) 2009 criteria $^{18}$. DM was defined as either known DM for which patients received medical treatment (either insulin or oral antidiabetics) or newly diagnosed DM, defined by an $\mathrm{HbAlc} \geq 48 \mathrm{mmol} / \mathrm{mol}(\geq 6.5 \%$ ), or FPG $\geq 7.0 \mathrm{mmol} / \mathrm{L}$. Pre-DM was defined by HbAlc $42-47 \mathrm{mmol} / \mathrm{mol}$ (6.0-6.4\%) and FPG 6.1$6.9 \mathrm{mmol} / \mathrm{L}$ and normoglycaemia by HbA1c levels $\leq 41 \mathrm{mmol} /$ $\mathrm{mol}(\leq 5.9 \%)$ or FPG $<6.1 \mathrm{mmol} / \mathrm{L}$. In addition, we studied glycaemia according to the American Diabetes Association (ADA) recommendations, which advocate for prediabetes an $\mathrm{HbA1c}$ $\geq 39 \mathrm{mmol} / \mathrm{mol}(5.7 \%)$ but $<48 \mathrm{mmol} / \mathrm{mol}(6.5 \%)$, and for new diabetes an $\mathrm{HbA} 1 \mathrm{c} \geq 48 \mathrm{mmol} / \mathrm{mol}(\geq 6.5 \%)$ (consistent with the IEC criteria). Sites were encouraged to assess the levels twice during hospitalisation, in case of any discordance between the diagnostic tests. Patients were classified into their "worst" category based on their lab results.

\section{STUDY ENDPOINTS, PROCEDURES, AND MONITORING}

Clinical endpoints were pre-specified, using the Academic Research Consortium definitions ${ }^{16}$. Myocardial infarction was defined by any creatine kinase concentration of more than double the upper limit of normal with elevated confirmatory cardiac biomarkers ${ }^{19}$. Revascularisation procedures were considered clinically indicated if the angiographic percent diameter stenosis of the then treated lesion was $\geq 50 \%$ in the presence of ischaemic signs or symptoms, or if the diameter stenosis was $\geq 70 \%$ irrespective of ischaemic signs or symptoms ${ }^{16,19}$. The main composite clinical endpoint of the present study comprised (components in hierarchical order): all-cause death, myocardial infarction, or revascularisation ${ }^{16}$.

Coronary interventions and concomitant medication did not differ from standard treatment and were performed according to current medical guidelines ${ }^{16}$. In general, dual antiplatelet therapy was prescribed for six to 12 months. Staged procedures were permitted within six weeks and did not count as events. Electrocardiograms were systematically assessed and recommended at routine clinical follow-up. Laboratory tests included systematic assessment of 
cardiac markers after the intervention and subsequent serial measurements in case of suspected ischaemia. Clinical follow-up data were obtained at visits to outpatient clinics or, if not feasible, by telephone follow-up or a medical questionnaire. There was no routine angiographic follow-up. A formal data safety monitoring committee reviewed the outcome data periodically. Data monitoring, processing of clinical outcome data, and independent clinical event adjudication were performed by an independent clinical research organisation (Diagram, Zwolle, the Netherlands).

\section{STATISTICAL ANALYSIS}

Data were reported as frequencies and percentages for dichotomous and categorical variables. Continuous variables were expressed as mean \pm standard deviation (SD). The time to primary endpoint and components thereof were assessed according to Kaplan-Meier methods; the log-rank test was applied for betweengroup comparisons. Pearson's chi-square test or Fisher's exact test was used to compare categorical variables, and the t-test to compare continuous variables. The relationship between pre-DM and the composite clinical endpoint of death, myocardial infarction and revascularisation was assessed with Cox proportional hazards analyses. A multivariate Cox proportional hazards analysis was used to adjust for potential confounders, accounting for differences in clinical outcome between the groups. Age, gender, body mass index, haemoglobin level at admission, hypertension, positive family history, hypercholesterolaemia, smoking, previous MI, previous revascularisation, multivessel disease and clinical syndrome at admission were included in the multivariate analysis. All statistical tests were two-tailed and p-values $<0.05$ were considered significant. Statistical analyses were performed with SPSS, Version 22 (IBM Corp., Armonk, NY, USA).

\section{Results}

From December 2012 to August 2015, a total of 3,514 participants in the BIO-RESORT trial were treated for obstructive coronary disease with contemporary DES. A total of 624 (18\%) trial participants had known DM for which they already received medical treatment with insulin or oral antidiabetics at the time of their PCI. In 2,362 trial participants without known DM, HbA1c levels and FPG were determined at the index procedure: 324 (14\%) had preDM, 169 (7\%) had newly diagnosed DM, and 1,869 (79\%) were normoglycaemic.

As a result, the glycaemic state was known in 2,986/3,514 $(85 \%)$ trial participants. They represent the study population of the present analysis, in which pre-DM was present in $324(11 \%)$, DM (known or new) in 793 (27\%), and normoglycaemia in 1,869 $(63 \%)$ patients. A total of $2,630(99.4 \%)$ patients completed 12 -month follow-up or had died. Only two $(0.07 \%)$ patients were actually lost to follow-up; $12(0.4 \%)$ patients withdrew consent during the trial and were censored (clinical outcome was used until time of withdrawal).

The baseline characteristics of the study population are presented in Table 1. The majority of participants were Caucasian
(95\%). Patients with pre-DM and DM were significantly older and had a higher body mass index than normoglycaemic patients. Furthermore, they had similar cardiovascular risk profiles with higher rates of hypertension, hypercholesterolaemia, and previous myocardial infarction and coronary revascularisation than normoglycaemic patients (Table 1). Information on medication prior to hospitalisation and at discharge is provided in Supplementary Table 1.

Clinical outcome data are presented in Table 2. The composite endpoint death, myocardial infarction or revascularisation at one year was met by $36(11.1 \%)$ pre-DM patients, $83(10.5 \%)$ diabetic patients, and $106(5.7 \%)$ normoglycaemic patients $(\mathrm{p}<0.001)$ (Figure 1). The individual components are presented in Figure 2. Mortality rates were higher in pre-DM (2.8\%) and DM (2.8\%) than in normoglycaemic patients $(1.2 \%, p=0.006)$ (Figure 2A). Similar revascularisation rates were found during one-year follow-up in patients with pre-DM and patients with DM (5.2\% and 5.9\%, respectively), which were significantly higher than revascularisation rates in normoglycaemic patients $(3.0 \%, \mathrm{p}<0.001)$ (Figure $2 \mathrm{C}$ ).

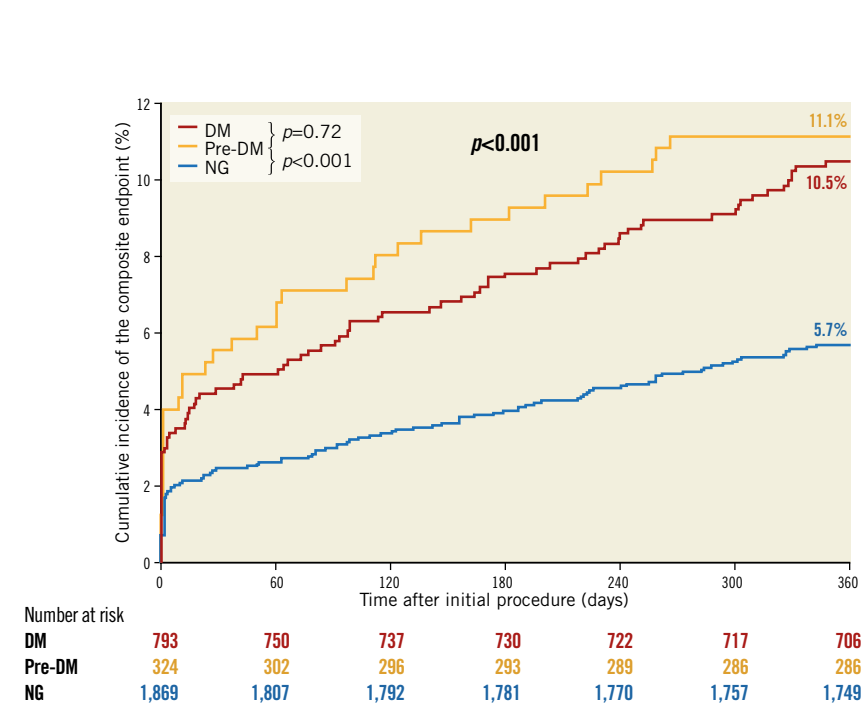

Figure 1. Kaplan-Meier curves of the composite endpoint. Composite clinical endpoint consisting of death, myocardial infarction, or revascularisation at one year.

Multivariate analysis demonstrated that pre-DM was independently associated with the composite endpoint at one-year follow-up: pre-DM patients had a twofold higher event risk than patients with normoglycaemia (adjusted HR 2.0, 95\% CI: 1.4-3.0). Adjusted hazard ratios are presented in Table 2 (unadjusted hazard ratios in Supplementary Table 2). There were no significant differences in one-year event risk between patients with pre-DM and those with DM. Revascularisation data on stent level can be found

\section{in Supplementary Table 3.}

When the ADA definitions were applied, 906 (30\%) patients were classified as prediabetic with a composite endpoint rate of $8.4 \%$ (vs. $5.1 \%$ in normoglycaemics and $10.6 \%$ in diabetics, $\mathrm{p}<0.001)$. Further details are presented in Supplementary Table 4. 
Table 1. Clinical characteristics.

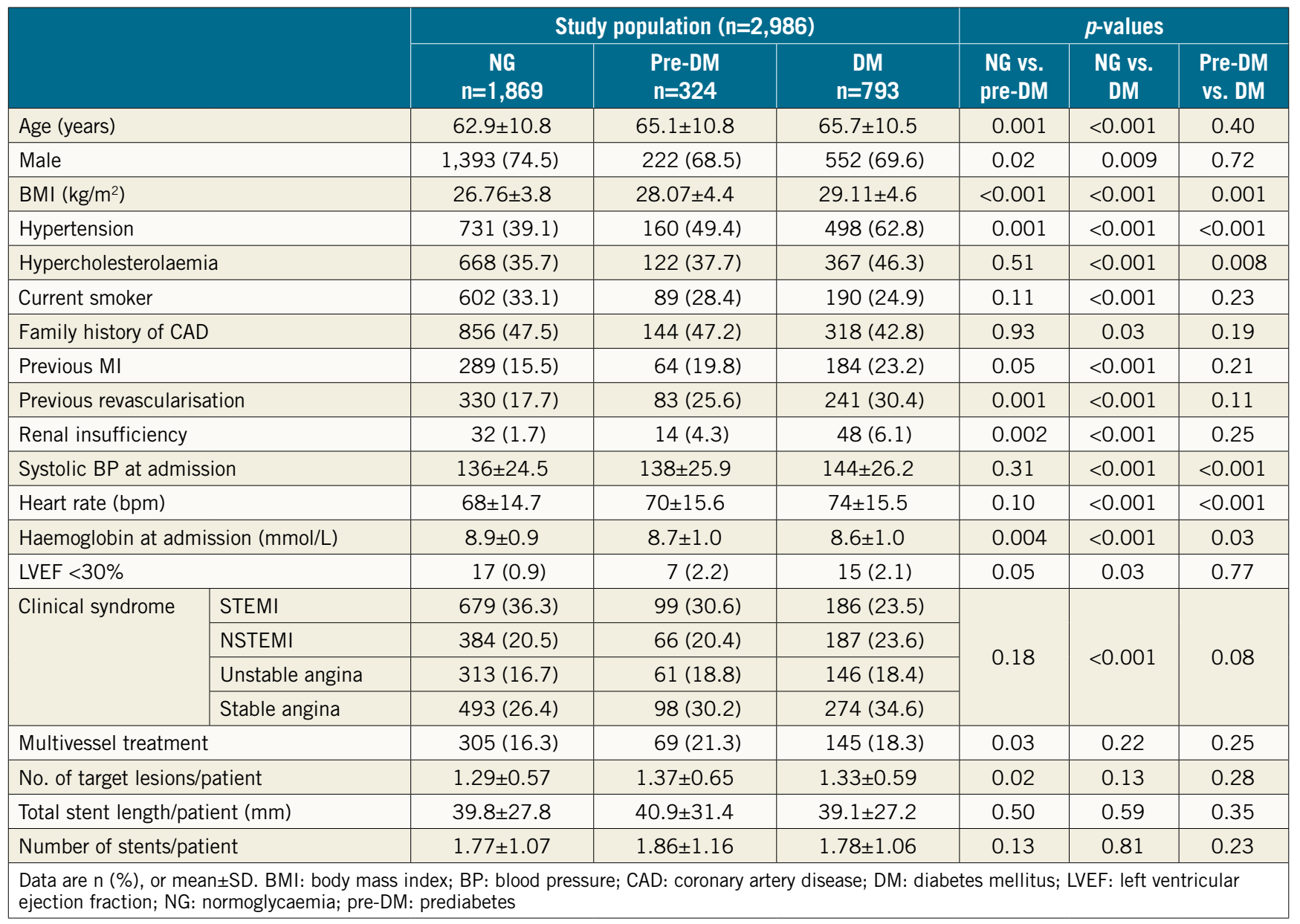

\section{Discussion}

\section{MAIN FINDINGS}

In the present prospective study in all-comers treated with contemporary DES, pre-DM at baseline was present in $14 \%$ of all non-DM patients. Patients with pre-DM had higher death and revascularisation rates than normoglycaemic patients, and the composite clinical endpoint rates were higher in patients with pre-DM (11.1\% versus 5.7\%). Multivariate analysis demonstrated a twofold higher event risk of death, MI and revascularisation in pre-DM than normoglycaemia.

Table 2. Events during 1-year follow-up.

\begin{tabular}{|c|c|c|c|c|c|c|}
\hline & \multicolumn{3}{|c|}{ Study population $(n=2,986)$} & \multirow{2}{*}{$\begin{array}{c}\begin{array}{c}\text { Log-rank } \\
\text { p-value }\end{array} \\
\text { Overall }\end{array}$} & \multicolumn{2}{|c|}{ Adjusted hazard ratios* (95\% CI) } \\
\hline & $\begin{array}{c}\text { NG } \\
n=1,869\end{array}$ & $\begin{array}{c}\text { Pre-DM } \\
n=324\end{array}$ & $\begin{array}{c}D M \\
n=793\end{array}$ & & $\begin{array}{l}\text { Pre-DM } \\
\text { vs. NG }\end{array}$ & $\begin{array}{l}\text { Pre-DM } \\
\text { vs. DM }\end{array}$ \\
\hline Death & $22(1.2)$ & $9(2.8)$ & $22(2.8)$ & 0.006 & $2.38(1.03-5.53)$ & $1.35(0.56-3.23)$ \\
\hline MI & $39(2.1)$ & $11(3.4)$ & $26(3.3)$ & 0.12 & $1.49(0.74-2.90)$ & $1.19(0.58-2.48)$ \\
\hline Periprocedural MI & $32(1.7)$ & $9(2.8)$ & $20(2.5)$ & 0.25 & $1.39(0.64-3.00)$ & $1.32(0.58-3.00)$ \\
\hline Any revascularisation" & $57(3.0)$ & $17(5.2)$ & $47(5.9)$ & 0.001 & $1.99(1.12-3.52)$ & $0.90(0.50-1.60)$ \\
\hline Target vessel revascularisation & $28(1.5)$ & $13(4.1)$ & $25(3.2)$ & 0.002 & $3.11(1.54-6.27)$ & $1.20(0.59-2.44)$ \\
\hline Target lesion revascularisation & $17(0.9)$ & $10(3.2)$ & $15(1.9)$ & 0.003 & $3.61(1.57-8.32)$ & $1.87(0.78-4.45)$ \\
\hline Death, MI, or any revascularisation & $106(5.7)$ & $36(11.1)$ & $83(10.5)$ & $<0.001$ & $2.01(1.35-3.00)$ & $1.20(0.79-1.82)$ \\
\hline Definite stent thrombosis & $4(0.2)$ & $1(0.3)$ & $4(0.5)$ & 0.46 & $1.75(0.18-17.5)$ & $2.04(0.18-23.04)$ \\
\hline
\end{tabular}


A

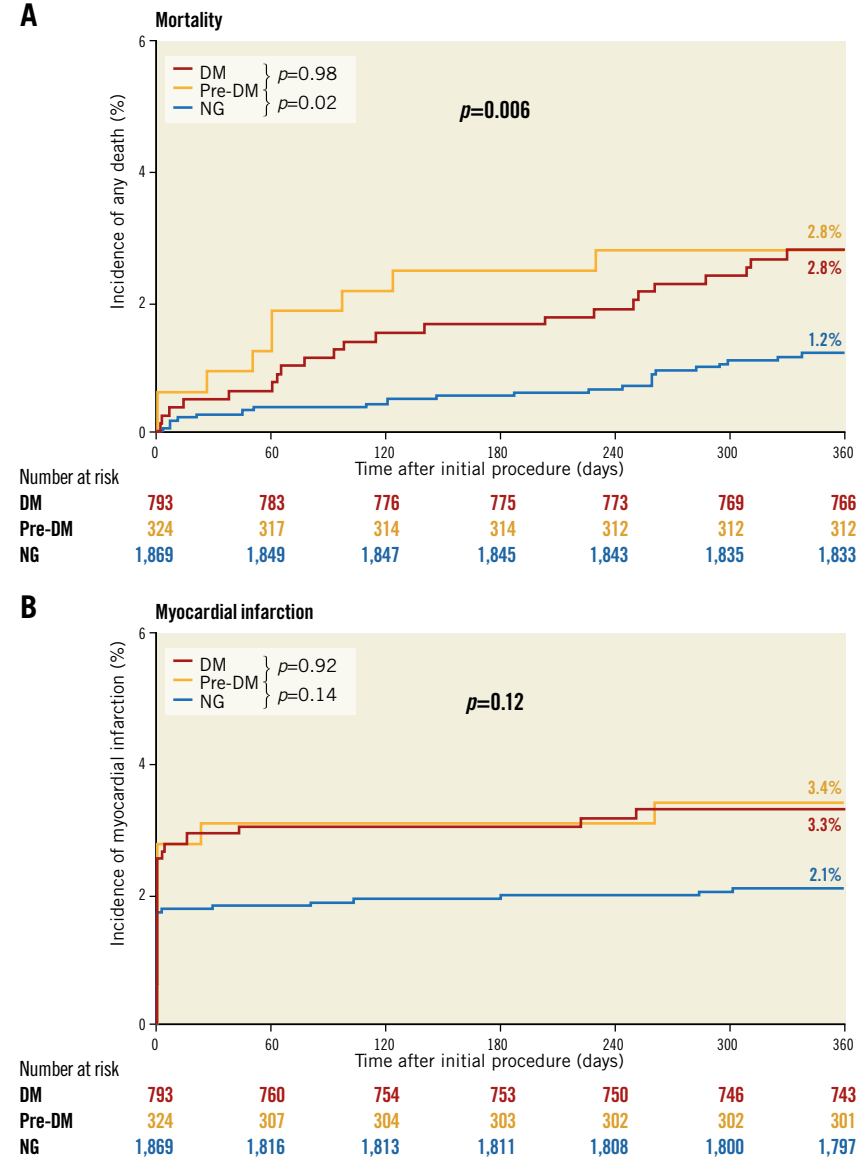

C

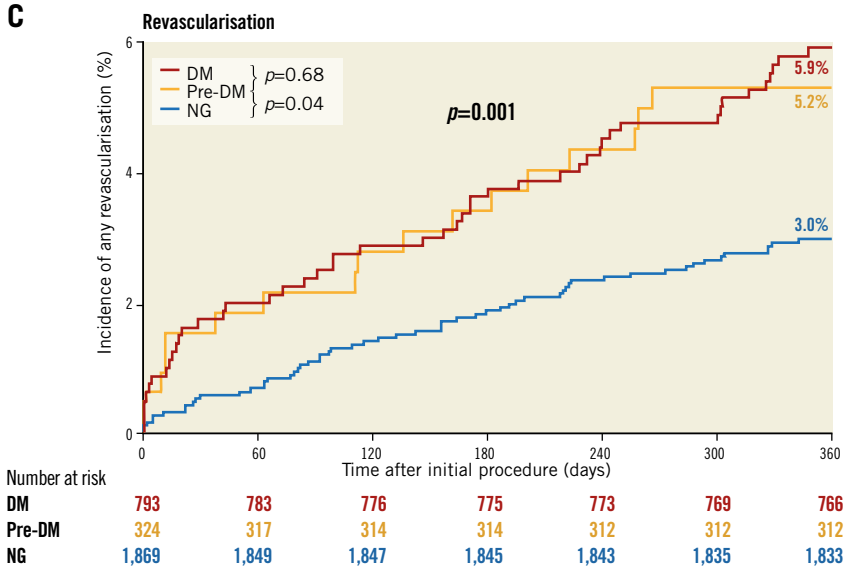

Figure 2. Kaplan-Meier curves of mortality, MI, and revascularisation. A) Event curves for mortality. B) Event curves for myocardial infarction. C) Event curves for revascularisation.

Patients with pre-DM and DM showed similar higher risk profiles versus patients with normoglycaemia, including older age, higher BMI, and higher rates of hypertension, hypercholesterolaemia, prior MI, and prior revascularisation. Most of these variables are components of the metabolic syndrome or linked to insulin resistance, suggesting that individuals with pre-DM have a "diabetic phenotype" 20 . Despite the use of contemporary DES, the rates of most clinical endpoints were at least as high in pre-DM as in DM, which underlines that PCI patients with pre-DM are prone to experience adverse clinical events. Our data suggest that, in non-diabetic all-comer patients scheduled for PCI, routine assessment of HbA1c and FPG may be of great value.

Further studies are needed to corroborate our findings, but the ease of HbA1c and FPG testing, relatively cheap cost and the pick-up of somewhere between $11 \%$ (using more conservative prediabetes criteria used in Europe) and 30\% using the ADA criteria mean that many patients at risk of diabetes and a small percentage (4\%) with new diabetes are identified with relevant clinical implications for both groups.

\section{PREDIABETES AND CARDIOVASCULAR RISK}

Although oral glucose tolerance testing (OGTT) has been suggested as the gold standard in the diagnosis of $\mathrm{DM}^{21}$, there has been an increased interest in HbAlc and cardiovascular risk. In 2008 the IEC, appointed by the ADA, the European Association for the Study of Diabetes, and the International Diabetes Federation, modified previous recommendations and suggested that $\mathrm{HbAlc}$ levels would represent a better diagnostic tool for DM than single measures of glucose concentration ${ }^{18}$. The IEC also recommended $\mathrm{HbAlc}$ of $6.0-6.4 \%(42-47 \mathrm{mmol} / \mathrm{mol})$ for the identification of an intermediate-risk group, i.e., prediabetes, since identification of these individuals provides an opportunity for intervention through lifestyle modification and pharmacological interventions to prevent progression to diabetes ${ }^{18}$. Pragmatic considerations which support the use of $\mathrm{HbAlc}$ are that no fasting is required, and that it can be assessed at any time, even shortly after an acute event. This flexibility is different from FPG assessment, which (ideally) should be performed at least four days after an MI to account for the acute phase response $e^{4-7}$. As for the comparison of glucose measures for the prediction of first-onset cardiovascular disease, results from a meta-analysis of patient-level data from 73 prospective studies suggest that the assessment of $\mathrm{HbAlc}$ is equal to or modestly better than the assessment of fasting, random, or postload plasma glucose $\mathrm{e}^{22}$.

Several general population studies have been performed to evaluate associations between pre-DM (according to different definitions) and cardiovascular events, finding an increased risk of composite cardiovascular events, coronary heart disease, stroke, and all-cause mortality ${ }^{7,823}$.

\section{PREVIOUS STUDIES ON PREDIABETES AND PCI OUTCOMES}

Studies on HbA1c level and clinical outcome after PCI have shown conflicting results. A recent meta-analysis of 20 observational studies involving 22,428 patients assessed the association between HbA1c level and clinical outcomes in non-diabetic patients with coronary artery disease, showing that elevated HbAlc levels (prediabetes) were associated with long-term mortality ${ }^{24}$. Only nine of the studies included in this meta-analysis concerned studies in which patients were treated with PCI, of which the majority was treated with bare metal stents or plain old balloon angioplasty (POBA). We will highlight the largest of these studies. 
A retrospective, observational study in 4,176 non-diabetic STEMI patients showed that HbAlc levels were independently associated with adverse outcome at one-year follow-up ${ }^{4}$. In contrast, a Chinese observational registry of STEMI patients with and without DM found that baseline HbAlc levels did not independently predict 30 -day clinical outcome $(90 \%$ had primary PCI with bare metal stents or DES ${ }^{25}$. Nevertheless, follow-up duration was very short and event rates were $10 w^{25}$. A single-centre study evaluated the relation between $\mathrm{HbA} 1 \mathrm{c}$ and major adverse cardiac events (MACE) in non-diabetic patients who underwent elective PCI with balloon angioplasty or bare metal stent implantation $^{26}$. The study showed that abnormal HbAlc was associated with significantly higher risk of MACE and target vessel revascularisation, although it should be noted that event rates were high, which can be explained by the use of bare metal stents. Another recently published retrospective cohort study assessed non-diabetic patients with ischaemic heart disease treated with PCI in 2010, with a mean follow-up of 42 months, showing that prediabetes as determined by HbAlc was not associated with long-term adverse cardiovascular outcomes ${ }^{27}$. Again, the majority of these patients $(>60 \%)$ were treated with bare metal stents and groups were relatively small.

A secondary analysis of the EARLY ACS trial showed similar rates of pre-DM as compared to our trial, in patients who were admitted to the hospital with non-ST-elevation acute coronary syndromes, treated either with PCI or CABG. Their primary outcome was a composite of all-cause death or myocardial infarction at 30 days, showing no significant differences in event rates in prediabetic patients as compared to diabetic patients ${ }^{28}$.

\section{ADDED VALUE AND CLINICAL IMPLICATIONS}

The previously discussed studies assessed only specific subsets of PCI patients (i.e., patients with DM, elective patients, or STEMI patients), and generally used techniques or devices that have been largely replaced (i.e., balloon angioplasty, bare metal stents, or first-generation DES) ${ }^{4,24-28}$. Our current study, on the other hand, reports findings of a recent prospective multicentre PCI study in all-comers who were all treated with contemporary newer-generation $\mathrm{DES}^{16}$. The findings obtained in patients with pre-DM, DM, and normoglycaemia provide present-day evidence of the importance of pre-DM for the clinical outcome of all-comer patients after PCI with contemporary DES.

Patients with coronary disease share risk factors with the metabolic syndrome and are therefore at an increased risk of developing $\mathrm{DM}^{5,29}$. It is important to identify patients with an abnormal glycaemic state as early as possible in order to prevent (or delay) the onset of DM. Routine assessment of glycaemic state in PCI patients may help to identify patients with pre-DM who are at an increased risk of adverse events. Close follow-up of these patients appears to be warranted. Particular attention should be paid to lifestyle counselling and/or pharmacological therapy to reduce the risk of developing DM, and intensified secondary prevention measures to prevent clinically apparent coronary artery disease (e.g., more aggressive lipid-lowering and hypertension treatment). Furthermore, identification of patients with new diabetes can lead to their immediately gaining the benefit of newer diabetes therapies that decrease MACE and mortality in patients with diabetes and cardiovascular disease ${ }^{30}$.

\section{Limitations}

The glycaemic state was known in $85 \%$ of the trial participants. While this percentage is reasonable, data from an even greater number of subjects would have been welcome. OGTT is a wellknown method to assess glucose metabolism and has detected more patients with DM in the general population as well as in patients with coronary disease, which is why ideally it would also have been assessed in order to complement the findings of the HbAlc and FPG measurements. However, OGTT is more labourintensive and onerous on patients, and thus more difficult to integrate into routine clinical practice. To ensure that results could be generalised as much as possible to common clinical settings, we based the diagnosis of pre-DM and newly diagnosed DM on HbA1c or FPG values determined at admission. Only in subjects who had a single HbAlc or FPG value determined at the time of discharge did we use that value. For prediabetes, there are currently no formal recommendations regarding repeating the test for confirmation; however, in the present analysis, in $85 \%$ of the patients, glycaemic testing was performed twice to confirm the diagnosis. Iron deficiency anaemia may increase $\mathrm{HbAlc}$ levels; however, pre-DM is still independently associated with the composite endpoint, despite including haemoglobin levels in the multivariate analysis. Finally, no data were available on the duration of DM before study enrolment or the occurrence of contrast-induced acute kidney injury, which count as predictors of worse prognosis.

\section{Conclusions}

Following PCI with contemporary drug-eluting stents, all-comer patients with pre-DM had a significantly higher risk of adverse events than normoglycaemic patients. In a non-diabetic patient population with obstructive coronary artery disease, routine assessment of HbA1c prior to PCI may be of clinical value.

\section{Impact on daily practice}

Routine assessment of $\mathrm{HbAlc}$ and fasting plasma glucose in patients requiring PCI with contemporary DES may help to identify a specific subpopulation who are at increased risk of experiencing adverse events. Close follow-up of these patients appears to be warranted. Particular attention should be paid to lifestyle counselling and/or pharmacological therapy to reduce the risk of developing DM, and to prevent clinically apparent coronary artery disease.

\section{Funding}

The BIO-RESORT study was funded equally by Biotronik, Boston Scientific, and Medtronic. 


\section{Conflict of interest statement}

C. von Birgelen was a consultant to Biotronik, Boston Scientific and Medtronic. N. Sattar reports personal fees from Boehringer Ingelheim, and Janssen, and grants/personal fees from AstraZeneca. The other authors have no conflicts of interest to declare.

\section{References}

1. Laiteerapong N, Cifu AS. Screening for Prediabetes and Type 2 Diabetes Mellitus. JAMA. 2016;315:697-8.

2. Huang Y, Cai X, Mai W, Li M, Hu Y. Association between prediabetes and risk of cardiovascular disease and all cause mortality: systematic review and meta-analysis. BMJ. 2016;355:i5953.

3. Authors/Task Force Members, Rydén L, Grant PJ, Anker SD, Berne C, Cosentino F, Danchin N, Deaton C, Escaned J, Hammes H, Huikuri H, Marre M, Marx N, Mellbin L, Ostergren J, Patrono C, Seferovic P, Sousa Uva M, Taskinen M, Tendera M, Tuomilehto J, Valensi P, Zamorano JL; ESC Committee for Practice Guidelines (CPG), Zamorano JL, Achenbach S, Baumgartner H, Bax JJ, Bueno H, Dean V, Deaton C, Erol C, Fagard R, Ferrari R, Hasdai D, Hoes AW, Kirchhof P, Knuuti J, Kolh P, Lancellotti P, Linhart A, Nihoyannopoulos P, Piepoli MF, Ponikowski P, Sirnes PA, Tamargo JL, Tendera M, Torbicki A, Wijns W, Windecker S; Document Reviewers, De Backer G, Sirnes PA, Ezquerra EA, Avogaro A, Badimon L, Baranova E, Baumgartner H, Betteridge J, Ceriello A, Fagard R, Funck-Brentano C, Gulba DC, Hasdai D, Hoes AW, Kjekshus JK, Knuuti J, Kolh P, Lev E, Mueller C, Neyses L, Nilsson PM, Perk J, Ponikowski P, Reiner Z, Sattar N, Schächinger V, Scheen A, Schirmer H, Strömberg A, Sudzhaeva S, Tamargo JL, Viigimaa M, Vlachopoulos C, Xuereb RG. ESC Guidelines on diabetes, pre-diabetes, and cardiovascular diseases developed in collaboration with the EASD: the Task Force on diabetes, pre-diabetes, and cardiovascular diseases of the European Society of Cardiology (ESC) and developed in collaboration with the European Association for the Study of Diabetes (EASD). Eur Heart J. 2013;34:3035-87.

4. Timmer JR, Hoekstra M, Nijsten MW, van der Horst IC, Ottervanger JP, Slingerland RJ, Dambrink JE, Bilo HJ, Zijlstra F, van't Hof AW. Prognostic value of admission glycosylated hemoglobin and glucose in nondiabetic patients with ST-segmentelevation myocardial infarction treated with percutaneous coronary intervention. Circulation. 2011;124:704-11.

5. American Diabetes Association. Diagnosis and classification of diabetes mellitus. Diabetes Care. 2014;37 Suppl 1:S81-90.

6. Sattar N, Preiss D. Screening for diabetes in patients with cardiovascular disease: HbA1c trumps oral glucose tolerance testing. Lancet Diabetes Endocrinol. 2016;4:560-2.

7. Gore OM, McGuire DK. A Test in Context: Hemoglobin A1c and Cardiovascular Disease. J Am Coll Cardiol. 2016;68: 2479-86.

8. Selvin E, Steffes MW, Zhu H, Wagenknecht L, Pankow J, Coresh J, Brancati FL. Glycated hemoglobin, diabetes, and cardiovascular risk in nondiabetic adults. $N$ Engl $J$ Med. 2010;362: 800-11.
9. Hadjadj S, Coisne D, Mauco G, Ragot S, Duengler F, Sosner P, Torremocha F, Herpin D, Marechaud R. Prognostic value of admission plasma glucose and $\mathrm{HbA}$ in acute myocardial infarction. Diabet Med. 2004;21:305-10.

10. Cakmak M, Cakmak N, Cetemen S, Tanriverdi H, Enc Y, Teskin O, Kilic ID. The value of admission glycosylated hemoglobin level in patients with acute myocardial infarction. Can $J$ Cardiol. 2008;24:375-8.

11. Bangalore S, Kumar S, Fusaro M, Amoroso N, Kirtane AJ, Byrne RA, Williams DO, Slater J, Cutlip DE, Feit F. Outcomes with various drug eluting or bare metal stents in patients with diabetes mellitus: mixed treatment comparison analysis of 22,844 patient years of follow-up from randomised trials. $B M J$. 2012;345:e5170.

12. Kedhi E, Généreux P, Palmerini T, McAndrew TC, Parise H, Mehran R, Dangas GD, Stone GW. Impact of coronary lesion complexity on drug-eluting stent outcomes in patients with and without diabetes mellitus: analysis from 18 pooled randomized trials. $J \mathrm{Am}$ Coll Cardiol. 2014;63:2111-8.

13. Farkouh ME, Domanski M, Sleeper LA, Siami FS, Dangas G, Mack M, Yang M, Cohen DJ, Rosenberg Y, Solomon SD, Desai AS, Gersh BJ, Magnuson EA, Lansky A, Boineau R, Weinberger J, Ramanathan K, Sousa JE, Rankin J, Bhargava B, Buse J, Hueb W, Smith CR, Muratov V, Bansilal S, King S 3rd, Bertrand M, Fuster V; FREEDOM Trial Investigators. Strategies for multivessel revascularization in patients with diabetes. $N$ Engl J Med. 2012;367: 2375-84.

14. Angiolillo DJ, Bernardo E, Sabaté M, Jimenez-Quevedo P, Costa MA, Palazuelos J, Hernandez-Antolin R, Moreno R, Escaned J, Alfonso F, Banuelos C, Guzman LA, Bass TA, Macaya C, Fernandez-Ortiz A. Impact of platelet reactivity on cardiovascular outcomes in patients with type 2 diabetes mellitus and coronary artery disease. J Am Coll Cardiol. 2007;50:1541-7.

15. Jiménez-Quevedo P, Sabaté M, Angiolillo DJ, Alfonso F, Hernandez-Antolin R, SanMartin M, Gomez-Hospital JA, Banuelos C, Escaned J, Moreno R, Fernandez C, FernandezAviles F, Macaya C; DIABETES Investigators. Long-term clinical benefit of sirolimus-eluting stent implantation in diabetic patients with de novo coronary stenoses: long-term results of the DIABETES trial. Eur Heart J. 2007;28:1946-52.

16. von Birgelen C, Kok MM, van der Heijden LC, Danse PW, Schotborgh CE, Scholte M, Gin RMTJ, Somi S, van Houwelingen KG, Stoel MG, de Man FHAF, Louwerenburg JHW, Hartmann M, Zocca P, Linssen GCM, van der Palen J, Doggen CJM, Löwik MM. Very thin strut biodegradable polymer everolimuseluting and sirolimus-eluting stents versus durable polymer zotarolimus-eluting stents in allcomers with coronary artery disease (BIO-RESORT): a three-arm, randomised, non-inferiority trial. Lancet. 2016;388:2607-17.

17. Chatterton H, Younger T, Fischer A, Khunti K; Programme Development Group. Risk identification and interventions to prevent type 2 diabetes in adults at high risk: summary of NICE guidance. BMJ. 2012;345:e4624. 
18. International Expert Committee. International Expert Committee report on the role of the A1C assay in the diagnosis of diabetes. Diabetes Care. 2009;32:1327-34.

19. Vranckx P, Cutlip DE, Mehran R, Kint P, Silber S, Windecker S, Serruys PW. Myocardial infarction adjudication in contemporary all-comer stent trials: balancing sensitivity and specificity. Addendum to the historical MI definitions used in stent studies. EuroIntervention. 2010;5:871-4.

20. Ferrannini E. Definition of intervention points in prediabetes. Lancet Diabetes Endocrinol. 2014;2:667-75.

21. Gyberg V, De Bacquer D, Kotseva K, De Backer G, Schnell O, Sundvall J, Tuemilehto J, Wood D, Ryden L; EUROASPIRE IV Investigators. Screening for dysglycaemia in patients with coronary artery disease as reflected by fasting glucose, oral glucose tolerance test, and HbA1c: a report from EUROASPIRE IV--a survey from the European Society of Cardiology. Eur Heart J. 2015;36:1171-7.

22. Emerging Risk Factors Collaboration, Di Angelantonio E, Gao P, Khan H, Butterworth AS, Wormser D, Kaptoge S, Kondapally, Seshasai SR, Thompson A, Sarwar N, Willeit P, Ridker PM, Barr EL, Khaw KT, Psaty BM, Brenner H, Balkau B, Dekker JM, Lawlor DA, Daimon M, Willeit J, Njølstad I, Nissinen A, Brunner EJ, Kuller LH, Price JF, Sundström J, Knuiman MW, Feskens EJ, Verschuren WM, Wald N, Bakker SJ, Whincup PH, Ford I, Goldbourt U, Gómez-de-la-Cámara A, Gallacher J, Simons LA, Rosengren A, Sutherland SE, Björkelund C, Blazer DG, Wassertheil-Smoller S, Onat A, Marín Ibañez A, Casiglia E, Jukema JW, Simpson LM, Giampaoli S, Nordestgaard BG, Selmer R, Wennberg P, Kauhanen J, Salonen JT, Dankner R, Barrett-Connor E, Kavousi M, Gudnason V, Evans D, Wallace RB, Cushman M, D'Agostino RB Sr, Umans JG, Kiyohara Y, Nakagawa H, Sato S, Gillum RF, Folsom AR, van der Schouw YT, Moons KG, Griffin SJ, Sattar N, Wareham NJ, Selvin E, Thompson SG, Danesh J. Glycated hemoglobin measurement and prediction of cardiovascular disease. JAMA. 2014; 311:1225-33.

23. Warren B, Pankow JS, Matsushita K, Punjabi NM, Daya NR, Grams M, Woodward M, Selvin E. Comparative prognostic performance of definitions of prediabetes: a prospective cohort analysis of the Atherosclerosis Risk in Communities (ARIC) study. Lancet Diabetes Endocrinol. 2017;5:34-42.

24. Geng J, Zhang Y, Wang B, Xie J, Xu B, Li J. Glycosylated hemoglobin levels and clinical outcomes in nondiabetic patients with coronary artery disease: A meta-analysis. Medicine (Baltimore). 2017;96:e6784.

25. Tian L, Zhu J, Liu L, Liang Y, Li J, Yang Y. Hemoglobin A1c and short-term outcomes in patients with acute myocardial infarction undergoing primary angioplasty: an observational multicenter study. Coron Artery Dis. 2013;24:16-22.

26. Corpus RA, O’Neill WW, Dion SR, Timmis GC, Devlin WH. Relation of hemoglobin A1c to rate of major adverse cardiac events in nondiabetic patients undergoing percutaneous coronary revascularization. Am J Cardiol. 2003;92:1282-6.

27. Cueva-Recalde JF, Ruiz-Arroyo JR, Roncalés GarciaBlanco F. Prediabetes and coronary artery disease: Outcome after revascularization procedures. [Article in English, Spanish]. Endocrinol Nutr. 2016;63:106-12.

28. Giraldez RR, Clare RM, Lopes RD, Dalby AJ, Prabhakaran D, Brogan GX Jr, Giugliano RP, James SK, Tanguay JF, Pollack CV Jr, Harrington RA, Braunwald E, Newby LK. Prevalence and clinical outcomes of undiagnosed diabetes mellitus and prediabetes among patients with high-risk non-ST segment elevation acute coronary syndrome. Am Heart J. 2013;165:918-25.e2.

29. Sattar N, Gaw N, Scherbakova O, Ford I, O'Reilly DS, Haffner SM, Isles C, Macfarlane PW, Packard CJ, Cobbe SM, Shepherd J. Metabolic syndrome with and without C-reactive protein as a predictor of coronary heart disease and diabetes in the West of Scotland Coronary Prevention Study. Circulation. 2003;108:414-9.

30. Sattar N, Petrie MC, Zinman B, Januzzi JL Jr. Novel Diabetes Drugs and the Cardiovascular Specialist. J Am Coll Cardiol. 2017;69:2646-56.

\section{Supplementary data}

Supplementary Table 1. Medication at hospitalisation and discharge.

Supplementary Table 2. Clinical outcome including hazard ratios. Supplementary Table 3. Revascularisations at 1-year follow-up; data on stent level.

Supplementary Table 4. Clinical outcome based on ADA definitions.

The supplementary data are published online at: http://www.pcronline.com/ eurointervention/142nd_issue/188 


\section{Supplementary data}

\section{Supplementary Table 1. Medication at hospitalisation and discharge.}

\begin{tabular}{|c|c|c|c|c|c|c|c|}
\hline & \multicolumn{3}{|c|}{ Study population $(n=2,986)$} & \multicolumn{4}{|c|}{$p$-values } \\
\hline & NG & Pre-DM & DM & Overall & NG vs. pre-DM & NG vs. DM & $\begin{array}{c}\text { Pre-DM vs. } \\
\text { DM }\end{array}$ \\
\hline & $\mathrm{n}=1,869$ & $\mathrm{n}=324$ & $\mathrm{n}=793$ & & & & \\
\hline \multicolumn{8}{|c|}{ Medication at hospitalisation } \\
\hline Aspirin & $998(53.4)$ & $193(59.6)$ & $527(66.5)$ & $<0.001$ & 0.04 & $<0.001$ & 0.03 \\
\hline Oral anticoagulants & $173(9.3)$ & $37(11.4)$ & $104(13.1)$ & 0.01 & 0.22 & 0.003 & 0.44 \\
\hline Statin & $929(49.7)$ & $194(59.9)$ & $568(71.6)$ & $<0.001$ & $<0.001$ & $<0.001$ & $<0.001$ \\
\hline Beta-blocker & $872(46.7)$ & $186(58.1)$ & $500(63.6)$ & $<0.001$ & $<0.001$ & $<0.001$ & 0.09 \\
\hline Antihypertensive drugs* & $751(40.2)$ & $177(54.6)$ & $538(67.8)$ & $<0.001$ & $<0.001$ & $<0.001$ & $<0.001$ \\
\hline ACE inhibitors & $382(20.5)$ & $88(27.5)$ & $295(37.5)$ & & & & \\
\hline ARB & $251(13.5)$ & $65(20.3)$ & $197(25.1)$ & & & & \\
\hline Calcium antagonist & $288(15.4)$ & 69 (21.6) & $227(28.9)$ & & & & \\
\hline Insulin & - & - & $220(27.7)$ & - & - & - & - \\
\hline Oral antidiabetic drugs & - & - & $491(61.9)$ & - & - & - & - \\
\hline \multicolumn{8}{|l|}{ Medication at discharge } \\
\hline Aspirin & $1,835(98.2)$ & $316(97.5)$ & $768(96.8)$ & 0.10 & 0.43 & 0.03 & 0.54 \\
\hline Ticagrelor & $869(46.5)$ & $152(46.9)$ & $326(41.1)$ & 0.03 & 0.89 & 0.01 & 0.08 \\
\hline Prasugrel & $30(1.6)$ & $8(2.5)$ & $17(2.1)$ & 0.43 & 0.27 & 0.34 & 0.74 \\
\hline Clopidogrel & 964 (51.6) & $161(49.7)$ & $443(55.9)$ & 0.07 & 0.53 & 0.04 & 0.06 \\
\hline Oral anticoagulants & $173(9.3)$ & $37(11.4)$ & $104(13.1)$ & 0.01 & 0.22 & 0.003 & 0.44 \\
\hline Statin & $1,764(94.4)$ & $307(94.8)$ & $726(91.6)$ & 0.02 & 0.79 & 0.007 & 0.07 \\
\hline
\end{tabular}




\begin{tabular}{|c|c|c|c|c|c|c|c|}
\hline Beta-blocker & $1,576(84.4)$ & $283(87.3)$ & $693(87.4)$ & 0.08 & 0.17 & 0.04 & 0.98 \\
\hline Antihypertensive drugs & $1,401(75.0)$ & $253(78.1)$ & $653(82.3)$ & $<0.001$ & 0.23 & $<0.001$ & 0.10 \\
\hline ACE inhibitors & $1,084(58.0)$ & $188(58.0)$ & $456(57.5)$ & & & & \\
\hline ARB & $210(14.6)$ & $47(22.7)$ & $130(28.3)$ & & & & \\
\hline Calcium antagonist & $280(15.0)$ & $67(20.7)$ & $228(28.8)$ & & & & \\
\hline Insulin & - & - & $227(28.6)$ & & - & - & - \\
\hline Oral antidiabetic drugs & - & - & $512(64.6)$ & - & - & - & - \\
\hline
\end{tabular}

* Antihypertensive drugs included ACE inhibitors, ARB and/or calcium antagonists.

ACE: angiotensin-converting enzyme; ARB: angiotensin receptor blocker; DM: diabetes mellitus; NG: normoglycaemia; pre-DM: prediabetes 
Supplementary Table 2. Clinical outcome including hazard ratios.

\begin{tabular}{|c|c|c|c|c|c|c|c|}
\hline & \multicolumn{3}{|c|}{$\begin{array}{c}\text { Study population } \\
\quad(n=2,645)\end{array}$} & \multicolumn{2}{|c|}{$\begin{array}{l}\text { Unadjusted hazard ratios } \\
\qquad(95 \% \mathrm{CI})\end{array}$} & \multicolumn{2}{|c|}{ Log-rank $p$-values } \\
\hline & NG & Pre-DM & DM & $\begin{array}{c}\text { Pre-DM } \\
\text { vs. } \\
\text { NG }\end{array}$ & $\begin{array}{c}\text { Pre-DM } \\
\text { vs. } \\
\text { DM }\end{array}$ & $\begin{array}{c}\text { Pre-DM } \\
\text { vs. } \\
\text { NG }\end{array}$ & $\begin{array}{c}\text { Pre-DM } \\
\text { vs. } \\
\text { DM } \\
\end{array}$ \\
\hline & $\mathrm{n}=1,869$ & $\mathrm{n}=324$ & $\mathrm{n}=793$ & & & $y$ & \\
\hline Death & $22(1.2)$ & $9(2.8)$ & $22(2.8)$ & $\begin{array}{c}2.40 \\
(1.10-5.20)\end{array}$ & $\begin{array}{c}1.01 \\
(0.47-2.19) \\
\end{array}$ & 0.02 & 0.98 \\
\hline MI & $39(2.1)$ & $11(3.4)$ & $26(3.3)$ & $\begin{array}{c}1.64 \\
(0.84-3.19) \\
\end{array}$ & $\begin{array}{c}1.04 \\
(0.51-2.10)\end{array}$ & 0.14 & 0.92 \\
\hline Periprocedural MI & $32(1.7)$ & $9(2.8)$ & $20(2.5)$ & $\begin{array}{c}1.62 \\
(0.77-3.40) \\
\end{array}$ & $\begin{array}{c}1.10 \\
(0.50-2.42)\end{array}$ & 0.19 & 0.81 \\
\hline Any revascularisation & $57(3.0)$ & $17(5.2)$ & $47(5.9)$ & $\begin{array}{c}1.77 \\
(1.03-3.05) \\
\end{array}$ & $\begin{array}{c}0.89 \\
(0.51-1.55) \\
\end{array}$ & 0.04 & 0.68 \\
\hline Target vessel revascularisation & $28(1.5)$ & $13(4.1)$ & $25(3.2)$ & $\begin{array}{c}2.76 \\
(1.43-5.34) \\
\end{array}$ & $\begin{array}{c}1.29 \\
(0.66-2.52) \\
\end{array}$ & 0.002 & 0.46 \\
\hline Target lesion revascularisation & $17(0.9)$ & $10(3.2)$ & $15(1.9)$ & $\begin{array}{c}3.49 \\
(1.60-7.63) \\
\end{array}$ & $\begin{array}{c}1.65 \\
(0.74-3.68) \\
\end{array}$ & 0.001 & 0.21 \\
\hline $\begin{array}{l}\text { Death, MI, or any } \\
\text { revascularisation }\end{array}$ & $106(5.7)$ & $36(11.1)$ & $83(10.5)$ & $\begin{array}{c}2.02 \\
(1.39-2.95) \\
\end{array}$ & $\begin{array}{c}1.07 \\
(0.73-1.59) \\
\end{array}$ & $<0.001$ & 0.72 \\
\hline Definite stent thrombosis & $4(0.2)$ & $1(0.3)$ & $4(0.5)$ & $\begin{array}{c}1.46 \\
(0.16-13.06)\end{array}$ & $\begin{array}{c}0.61 \\
(0.07-5.49)\end{array}$ & 0.73 & 0.66 \\
\hline
\end{tabular}

CI: confidence interval; DM: diabetes mellitus; MI: myocardial infarction; NG: normoglycaemia; Pre-DM: prediabetes 
Supplementary Table 3. Revascularisations at 1-year follow-up; data on stent level.

\begin{tabular}{|c|c|c|c|c|c|c|c|c|c|c|c|c|}
\hline & \multicolumn{3}{|c|}{ NG } & \multicolumn{4}{|c|}{ Pre-DM } & \multirow[b]{2}{*}{$\begin{array}{c}\text { Log- } \\
\text { rank } p \text { - } \\
\text { value }\end{array}$} & \multicolumn{3}{|c|}{ DM } & \multirow[b]{2}{*}{$\begin{array}{l}\text { Log- } \\
\text { rank } p \\
\text { value }\end{array}$} \\
\hline & All & $\begin{array}{c}\text { Biodegradable } \\
\text { polymer } \\
\text { DES }\end{array}$ & $\begin{array}{c}\text { Durable } \\
\text { polymer } \\
\text { DES }\end{array}$ & $\begin{array}{c}\text { Log- } \\
\text { rank } p \text { - } \\
\text { value }\end{array}$ & All & $\begin{array}{c}\text { Biodegradable } \\
\text { polymer } \\
\text { DES }\end{array}$ & $\begin{array}{c}\text { Durable } \\
\text { polymer } \\
\text { DES }\end{array}$ & & All & $\begin{array}{c}\text { Biodegradable } \\
\text { polymer } \\
\text { DES }\end{array}$ & $\begin{array}{c}\text { Durable } \\
\text { polymer } \\
\text { DES }\end{array}$ & \\
\hline & $\mathrm{n}=1,869$ & $\mathrm{n}=1,246$ & $\mathrm{n}=623$ & & $\mathrm{n}=324$ & $\mathrm{n}=212$ & $\mathrm{n}=112$ & (2) & $\mathrm{n}=793$ & $\mathrm{n}=533$ & $\mathrm{n}=260$ & \\
\hline $\begin{array}{l}\text { Any } \\
\text { revascularisation }\end{array}$ & $57(3.0)$ & $31(2.5)$ & $26(4.2)$ & 0.05 & $17(5.2)$ & $9(4.4)$ & $8(7.3)$ & 0.26 & $47(5.9)$ & $30(5.7)$ & $17(6.8)$ & 0.59 \\
\hline $\begin{array}{l}\text { Target vessel } \\
\text { revascularisation }\end{array}$ & $28(1.5)$ & $14(1.1)$ & $14(2.3)$ & 0.06 & $13(4.1)$ & $5(2.4)$ & $8(7.3)$ & 0.04 & $25(3.2)$ & $17(3.2)$ & $8(3.2)$ & 0.96 \\
\hline $\begin{array}{l}\text { Target lesion } \\
\text { revascularisation }\end{array}$ & $17(0.9)$ & $10(0.8)$ & $7(1.1)$ & 0.50 & $10(3.2)$ & $3(1.5)$ & $7(6.4)$ & 0.02 & $15(1.9)$ & $12(2.3)$ & $3(1.2)$ & 0.30 \\
\hline
\end{tabular}

Biodegradable polymer DES used were either Orsiro (Biotronik, Bülach, Switzerland) or SYNERGY ${ }^{\mathrm{TM}}$ (Boston Scientific, Marlborough, MA, USA); durable polymer DES was Resolute Integrity ${ }^{\circledR}$ (Medtronic, Minneapolis, MN, USA).

DES: drug-eluting stent; DM: diabetes mellitus; NG: normoglycaemia; Pre-DM: prediabetes 
Supplementary Table 4. Clinical events by glycaemic state based on ADA definitions.

\begin{tabular}{|l|c|c|c|c|}
\hline & \multicolumn{3}{|c|}{$\begin{array}{c}\text { Study population } \\
\text { (n=2,986) }\end{array}$} & $\begin{array}{c}\text { Log-rank } \text { p- } \\
\text { value }\end{array}$ \\
\hline & NG & Pre-DM & DM & Overall \\
\hline & $\mathrm{n}=1,288$ & $\mathrm{n}=906$ & $\mathrm{n}=792$ & \\
\hline Death & $13(1.0)$ & $18(2.0)$ & $22(2.8)$ & 0.01 \\
\hline MI & $22(1.7)$ & $28(3.1)$ & $26(3.3)$ & 0.04 \\
\hline Any revascularisation $\dagger$ & $35(2.7)$ & $38(4.3)$ & $48(6.2)$ & 0.001 \\
\hline \multicolumn{1}{|c|}{ Target vessel revascularisation } & $16(1.3)$ & $24(2.7)$ & $26(3.3)$ & 0.005 \\
\hline \multicolumn{1}{|c|}{ Target lesion revascularisation } \\
$\begin{array}{l}\text { Death, } \\
\text { MI, or }\end{array}$ & $11(0.9)$ & $15(1.7)$ & $16(2.1)$ & 0.06 \\
\hline
\end{tabular}

Event rates, expressed as n (\%), were calculated by Kaplan-Meier method.

$\dagger$ Revascularisations comprised any target vessel and non-target vessel revascularisation, treated by PCI and/or CABG; all revascularisations were clinically indicated.

* Hazard ratios adjusted for age, gender, body mass index, haemoglobin level, hypertension, hypercholesterolaemia, positive family history, smoking, previous MI, previous revascularisation, multivessel disease and clinical syndrome using a Cox proportional hazards model.

CI: confidence interval; DM: diabetes mellitus; MI: myocardial infarction; NG: normoglycaemia; Pre-DM: prediabetes 